\title{
Olahraga yang Aman di Masa Pandemi COVID-19 untuk Meningkatkan Imunitas Tubuh
}

\author{
Yuliana \\ Departemen Anatomi, Fakultas Kedokteran, Universitas Udayana \\ Email: yuliana@unud.ac.id
}

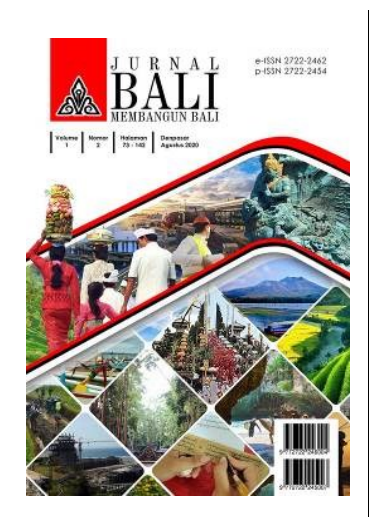

Sejarah Artikel

Diterima pada 14 Mei 2020

Direvisi pada 19 Mei 2020

Disetujui pada 29 Mei 2020

\begin{abstract}
Abstrak
Tujuan: Tujuan tinjauan pustaka ini adalah mengetahui olahraga yang aman dilakukan pada masa pandemi COVID-19 untuk meningkatkan imunitas tubuh bagi masyarakat. Metode penelitian: Metode yang dilakukan dalam pemilihan referensi pustaka adalah dengan menggunakan jurnal Pubmed dan Elsevier, dengan kata kunci olahraga, corona, dan disortir hingga lima tahun terakhir.

Temuan: Hasilnya didapatkan bahwa olahraga sebaiknya dilakukan dalam ruangan untuk mengurangi penyebaran virus corona (COVID-19).

Implikasi: Makna dari tulisan ini adalah tidak semua olahraga aman dilakukan pada masa pandemi ini. Yang aman adalah yoga, sepeda statis, senam, latihan otot, maupun peregangan yang dilakukan di rumah.
\end{abstract}

Kata kunci: olahraga, COVID-19, aman, pandemi, imunitas

\begin{abstract}
Purpose: The purpose of this review is to understand which sport that is safe to be done on COVID-19 pandemic in order to increase immunity for society.

Research methods: Methodology is by journal searching using Pubmed and Elsevier, with keywords sport and COVID-19, then it was filtered using the last five year journals. Findings: Result revealed that sport is safe to be done indoor to reduce COVID-19 transmission.

Implications: Significance of this paper is not all sports considered safe in corona pandemic. Safe sports are yoga, static cycling, gymnastics, muscle exercise, or stretching at home.
\end{abstract}

Keywords: sport, COVID-19, safe, pandemic, immunity

\section{PENDAHULUAN}

Pada bulan Desember 2019, dunia dikejutkan dengan berita adanya wabah virus corona baru yang diberi nama 2019-novel corona virus (SARS-CoV-2) di kota Wuhan, provinsi Hubei, China. Virus ini juga dikenal dengan nama COVID-19 (Corona Virus Disease 2019) (Dutheil et al., 2020). Dengan adanya pergerakan masyarakat yang masih melakukan perjalanan dan menganggap remeh akan virus ini, maka muncul pandemi virus corona pada tahun 2020. WHO menyatakan terjadi pandemi karena telah menyerang seluruh dunia dan menyebabkan tingginya angka infeksi, morbiditas, dan mortalitas (Chan et al., 2020).

Gambaran klinis infeksi COVID-19 adalah demam, batuk, sesak napas, diare, dan nyeri kepala. Virus ini dapat ditularkan dari manusia ke manusia melalui droplet, aerosol, bahkan melalui objek maupun permukaan benda yang terkontaminasi dengan 
droplet dari orang yang menderita sakit. Strategi pencegahan yang baik dapat mengurangi tingkat penyebaran penyakit (Halabchi et al., 2020).

Pandemi COVID-19 pada tahun 2020 ini membawa banyak perubahan dalam kehidupan masyarakat. Semua harus dilakukan di rumah. Belajar, bekerja, beribadah, bahkan olahragapun dianjurkan di rumah. Sebenarnya olahraga bisa dilakukan di luar rumah maupun di dalam rumah. Namun, di masa pandemi corona, olahraga harus dilakukan dengan cermat dan dipertimbangkan dengan seksama.

Banyak orang menganggap yang penting olahraga dengan jarak terpisah minimal satu meter dan memakai masker sudah cukup aman. Padahal tidak semua olahraga di luar ruangan itu aman. Jika memang olahraga di luar ruangan aman, mengapa lomba olahraga nasional maupun internasional itu ditunda sampai waktu yang tidak ditentukan? Tak sedikit pula kegiatan olahraga yang dibatalkan dalam skala internasional (Halabachi et al., 2020).

Olahraga sebenarnya memiliki banyak efek positif. Olahraga ini sering disebut aktivitas fisik untuk meningkatkan kesehatan dan kebugaran. Manfaat positif olahraga adalah meningkatkan perkembangan pribadi dan psikososial, tidur lebih nyenyak, bahkan dapat mengurangi ketergantungan terhadap alkohol (Lopez et al., 2016). Beberapa penelitian menyatakan bahwa olahraga dapat mengurangi demensia (pikun). Efek olahraga juga bisa negatif jika dilakukan berlebihan, misalnya kelelahan (burnout), cedera, ataupun luka karena terjatuh atau kurang berhati-hati (Malm et al., 2019).

Olahraga yang dilakukan secara tepat pasti akan membawa dampak positif baik secara fisiologis maupun psikologis. Di masa pandemi ini, haruslah dipilih olahraga yang baik. Jika tidak memilih olahraga yang tepat, bukan tidak mungkin dengan berolahraga malah berisiko terjadi peningkatan penularan COVID-19. Tujuan tinjauan pustaka ini adalah mengetahui olahraga yang aman untuk meningkatkan imunitas tubuh pada masa pandemi COVID-19.

\section{METODE}

Metode yang dilakukan dalam pemilihan referensi pustaka adalah dengan menggunakan jurnal pubmed dan elsevier, dengan kata kunci olahraga, corona, dan disortir hingga lima tahun terakhir.

\section{PEMBAHASAN}

Olahraga di masa corona ini menjadi suatu kebutuhan pokok. Olahraga dapat mengusir kebosanan di rumah, meningkatkan imunitas, mengisi waktu luang, dan meningkatkan energi dalam menjalani rutinitas sehari-hari. Kurangnya aktivitas fisik 
selama masa pandemi dapat meningkatkan risiko penyakit dan obesitas. Asupan makanan meningkat disertai aktivitas fisik berkurang akan meningkatkan obesitas. Aktivitas fisik yang tepat dapat mengurangi stres dan kecemasan. Kadar endorfin akan meningkat setelah berolahraga (Malt et al., 2019).

Sebenarnya ada penelitian yang mengatakan bahwa olahraga adalah pedang bermata dua. Di satu sisi menguntungkan, namun di sisi lain dapat membahayakan. Olahraga dikatakan dapat membuat orang awet muda. Namun, tidak jarang kita dengar ada orang yang meninggal di lapangan olahraga karena serangan jantung (Stamakis et al., 2019). Gangguan gastrointestinal bisa juga terjadi jika olahraga berlebihan. Dengan mempertimbangkan berbagai faktor, maka dosis olahraga itu berbeda bagi setiap usia dan kondisi fisik individu (Malm et al., 2019).

Keadaan udara pada masa pandemi Corona ini juga memiliki dua sisi yang berbeda. Di satu sisi, konsentrasi nitrogen dioksida berkurang jauh sejak adanya larangan dan pembatasan transportasi di Wuhan. Sekolah dan kampus ditutup untuk mengurangi penyebaran penyakit dan karantina masal (Wilder-Smith and Freedman, 2020). Hal ini diikuti juga dengan kota lain yang ada di sekitarnya. Bahkan emisi karbondioksida juga menurun (Dutheil, 2020). Namun udara juga dikontaminasi oleh droplet masyarakat penderita COVID-19 (orang tanpa gejala) yang masih berlalu lalang harus melakukan berbagai aktivitas di luar rumah. Tentunya hal ini harus dipertimbangkan dengan cermat saat melakukan olahraga di luar rumah.

Jika terpaksa berolahraga di luar rumah dan menggunakan fasilitas umum, hendaknya melakukan desinfeksi semua peralatan sebelum dan setelahnya. Yang pertama harus dilakukan setelah berolahraga adalah mencuci tangan. Tangan dibasahi dan diberikan sabun, kemudian digosok minimal 20 detik, selanjutnya dikeringkan dengan handuk bersih. Lebih baik lagi jika menggunakan tisu sekali pakai. Hand sanitizer $60 \%$ dianggap kurang efektif. Kita wajib menghindari menyentuh wajah dan leher dengan tangan sebelum mencuci tangan secara bersih (Zhu, 2020).

Pada prinsipnya, peningkatan kemungkinan untuk kontak dengan orang yang terinfeksi ataupun melakukan hal yang dapat menurunkan sistem imun, akan meningkatkan risiko kita untuk terinfeksi virus corona. Jika awalnya kita tidak terbiasa berolahraga, disarankan untuk melakukan olahraga secara bertahap. Olahraga berlebihan secara mendadak dapat menurunkan sistem imun (Zhu, 2020).

Olahraga meningkatkan respon sel dan sistem imun dalam hitungan detik sampai menit setelah mulai berolahraga. Jadi disarankan olahraga secara rutin supaya imunitas terpelihara dengan baik. Olahraga meningkatkan fight or flight stress response, artinya respon tubuh terhadap stress akan lebih baik. Tubuh memiliki 
kemampuan untuk mengukur dan bereaksi terhadap suatu stres dengan lebih efektif (Zhu, 2020).

Rekomendasi mengenai olahraga pada masa pandemi corona tergantung keadaan kesehatan masing-masing individu. Pada orang yang sehat atau tak memiliki gejala apapun, dianjurkan untuk olahraga di lingkungan pribadi (misalnya di rumah) dengan ventilasi yang bagus dan menggunakan alat pribadi. Untuk penderita infeksi saluran pernapasan atas dengan gejala hanya terbatas di atas leher, maka diperbolehkan olahraga ringan sekitar 10 menit dengan tes jogging dahulu, jika kondisi memburuk, maka segera dihentikan dan tidak boleh olahraga sampai sembuh sempurna. Pasien dengan gejala infeksi saluran pernapasan atas yang disertai keluhan di bawah leher, mengalami sakit otot, demam, dan ada gejala saluran cerna, maupun sesak napas atau gangguan organ lain, maka tidak diperbolehkan sama sekali untuk berolahraga sampai sembuh sempurna. Pada masa pandemi ini, semua orang tidak diperbolehkan melakukan olahraga dengan intensitas tinggi, bahkan harus membatalkan semua olahraga kompetisi (perlombaan). Hal ini dilakukan karena orang yang tidak menunjukkan gejala infeksi corona pun dapat menularkan penyakit pada orang lain (carrier) (Halabchi et al., 2020).

Rekomendasi tersebut di atas memiliki beberapa alasan dan latar belakang. Olahraga dengan tingkat/intensitas sedang dapat meningkatkan imunitas tubuh melawan infeksi pernapasan akibat virus. Melakukan aktivitas fisik (olahraga) intensitas sedang dapat meningkatkan netrofil dan sel natural killer serta konsentrasi IgA dalam saliva. Inflamasi (peradangan) akan berkurang dan imunitas (kekebalan) tubuh akan meningkat. Yang perlu diingat adalah olahraga dengan intensitas tinggi dapat menurunkan kekebalan dan risiko infeksi pernapasan makin meningkat (Halabchi et al., 2020).

Rekomendasi lainnya adalah berdasarkan kelompok umur sesuai panduan WHO pada tahun 2017. Semua anak dan remaja mulai umur 6-17 tahun disarankan olahraga 60 menit sehari dengan intensitas sedang. Jika olahraga intensitas tinggi, maka frekuensi dapat diperpendek menjadi 3 kali seminggu. Jenis olahraga ini dapat pula diikuti dengan aktivitas penguatan otot 3 kali seminggu. Berlari dan melompat diperbolehkan untuk meningkatkan densitas tulang. Guna olahraga pada usia ini adalah untuk perkembangan otot, tulang, dan saraf; mempertahankan berat badan yang sehat dan mencapai kesehatan mental yang prima; meningkatkan perkembangan sosial, rasa percaya diri, dan memperbaiki kemampuan belajar (Malm et al., 2019). 
Bagi kelompok usia 18-64 tahun, WHO menyarankan untuk berolahraga minimal 150 menit seminggu dengan intensitas sedang. Jika dilakukan dengan intensitas tinggi disarankan 75 menit seminggu yang terbagi dalam 3 kali pertemuan. Latihan penguatan otot disarankan 2 kali seminggu. Keuntungan olahraga di usia ini adalah meningkatkan kekuatan otot, kemampuan kapasitas kerja aerobik, dan menurunkan risiko penyakit metabolik, patah tulang, dan kanker (Malm et al., 2019).

Untuk usia di atas 64 tahun lebih disarankan untuk latihan kekuatan otot dan keseimbangan. Fungsi olahraga pada usia ini adalah memperbaiki kapasitas kerja, kekuatan otot, dan keseimbangan. Rekomendasi bersifat universal. Namun perlu diingat untuk disesuaikan bagi orang yang memiliki kondisi medis tertentu. Umur, genetik, lingkungan, dan diet memegang peranan penting. Konsultasi medis amat disarankan sebelum memulai olahraga (Malm et al., 2019).

Olahraga aerobik berguna untuk menurunkan berat badan yang berlebih, menurunkan risiko sindrom metabolik, menormalkan kadar lemak darah, dan mengurangi risiko kanker. Olahraga yang melatih kekuatan otot dapat menurunkan atropi otot, risiko jatuh, dan osteoporosis pada orangtua. Obesitas dicegah dan kinerja kognitif diperbaiki, sehingga demensia (pikun) bisa dicegah. Densitas tulang bertambah sehingga risiko jatuh berkurang. Kualitas tidur akan membaik (Malm et al., 2019).

Olahraga yang sesuai dilakukan di rumah adalah aerobik, misalnya berjalan di dalam rumah, latihan kekuatan, peregangan, dan latihan keseimbangan. Sepeda statis, latihan kombinasi, ataupun jalan santai di luar rumah masih diperbolehkan sambil menjaga jarak aman. Namun, olahraga di tempat umum dan lingkungan padat akan membawa risiko penularan yang lebih besar (Chen et al., 2020).

Olahraga kompetisi sebaiknya dihentikan. Jika olahraga kompetisi terpaksa dilakukan, maka atlet akan mengalami penurunan imunitas karena latihan berlebihan. Kontak dekat dengan atlet yang lain, termasuk berbagi alat dan fasilitas olahraga, misalnya kolam renang akan meningkatkan risiko penularan. Belum lagi risiko yang mesti dialami oleh penonton yang berdesakan ingin menyaksikan pertandingan. Andaikata pertandingan tidak bisa ditunda, maka harus dilakukan tanpa adanya penonton dan menerapkan prinsip sanitasi serta proteksi ketat (Chen et al., 2020).

Olahraga di rumah dengan alat sederhana sangat cocok untuk meminimalkan risiko penularan dan mengurangi risiko penyakit kronis. Naik turun tangga, senam, yoga, angkat beban, sit up, push up, maupun senam qiqong juga merupakan alternative yang baik. Olahraga tersebut hanya membutuhkan sedikit ruangan dan bisa dilakukan di setiap waktu. Video olahraga yang tersedia di internet juga bisa 
dimanfaatkan untuk mempertahankan kesehatan fisik dan mental selama periode kritis pandemi ini (Chen et al., 2020).

Olahraga sebaiknya dilakukan minimal 30 menit dengan intensitas sedang setiap hari. Alternatif lain adalah dilakukan 20 menit dengan intensitas berat. Namun untuk intensitas berat sebaiknya ditunda selama masa pandemi corona. Orangtua dan mereka yang memiliki penyakit kardiovaskular, gangguan tulang, ataupun penyakit paru kronis harus berkonsultasi dahulu dengan dokter sebelum berolahraga (Luan et al., 2019; Zhu, 2019).

Beberapa faktor yang penting dimonitor selama olahraga adalah beban latihan/olahraga, pemulihan, dan sakit/cedera. Beban latihan meliputi lamanya latihan, frekuensi, dan intensitas. Yang diperhatikan saat pemulihan adalah denyut jantung saat istirahat, kelelahan, nafsu makan, dan kualitas tidur. Frekuensi, tipe, penyebab, tempat/posisi tubuh terjadinya sakit/cedera, serta berapa lama waktu terjadinya sakit/cedera adalah hal penting yang tidak boleh dilewatkan (Malm et al., 2019). Dengan memonitor berbagai hal tersebut secara mandiri di rumah, diharapkan olahraga bisa berlangsung aman dan meningkatkan imunitas pada masa pandemi corona ini.

\section{KESIMPULAN}

Peningkatan risiko penyebaran infeksi COVID-19 telah membuat masyarakat waspada saat berolahraga di luar rumah. Melakukan segala aktivitas di rumah adalah tindakan yang aman. Olahraga di rumah jauh lebih aman daripada di luar. Ada banyak pilihan olahraga, misalnya yoga, sepeda statis, senam dengan bantuan video di internet, peregangan, sit up, push up, maupun qiqong. Waktu yang disarankan minimal 30 menit, diusahakan setiap hari.

Untuk orang sehat direkomendasikan olahraga intensitas sedang. Namun untuk orang yang menderita infeksi saluran pernapasan atas, maka disarankan hanya olahraga selama 10 menit. Jika ada perburukan gejala, olahraga segera dihentikan.

Bagi yang memiliki gejala infeksi saluran pernapasan bawah, mengalami sakit otot, demam, dan ada gejala saluran cerna, maupun sesak napas atau gangguan organ lain, maka tidak diperbolehkan sama sekali untuk berolahraga sampai sembuh sempurna. Semua olahraga intensitas tinggi termasuk kompetisi/perlombaan olahraga harus dihentikan pada masa ini. 


\section{REFERENSI}

Chan, J.F., Yuan, S., Kok, K., To, K.K., Chu, H., Yang, J., Xing, F., Liu, J., Yip, C.C., Poon, R.W., Tsoi, H., Lo, S.K., Chan, K., Poon, V.K., Chan, W., Ip, J.D., Cai, J., Cheng, V.C., Chen, H., Hui, C.K., Yuen, K.Y. 2020. A familial cluster of pneumonia associated with the 2019 novel coronavirus indicating person-toperson transmission: a study of a family cluster. Lancet, 395, 514e523. https://doi.org/10.1016/S0140-6736(20)30154-9.

Chen. P., Mao, L., Nassis, G.P., Harmer, P., Ainsworth, B.E., Li, F. 2020. Wuhan coronavirus (2019-nCoV): The need to maintain regular physical activity while taking precautions. J Sport Health Sci., 9 (2), pp.103-4.

Dutheil, F., Baker, J.S., Navel V. 2020. COVID-19 as a factor influencing air pollution? Environmental Pollution, 263, pp.1-3.

Halabchi, F., Ahmadinejad, Z., Ghaffari, M.S. 2020. COVID-19 Epidemic: Exercise or Not to Exercise; That is the Question! Asian J Sports Med. In Press. doi: 10.5812/asjsm. 102630.

Lopez V.F.J., Rodriguez G.P.L., Garcia, C.E., Perez, S.J.J. 2016. Relationship between sport and physical activity and alcohol consumption among adolescents students in Murcia. Arch. Argent. Pediatr.,114, pp.101-106.

Luan, X., Tian, X., Zhang, H., Huang, R., Li, N., Chen, P., et al. 2019. Exercise as a prescription for patients with various diseases. J Sport Health Sci.,8, pp.422-41.

Malm, C., Jakobsson, J., Isaksson A. 2019. Physical Activity and Sports-Real Health Benefits: A Review with Insight into the Public Health of Sweden. Sports, 7(127), pp.1-28.

Wilder-Smith, A., Freedman, D.O. 2020. Isolation, quarantine, social distancing and community containment: pivotal role for old-style public health measures in the novel coronavirus (2019-nCoV) outbreak. J. Trav. Med., 27(2), pp.1-4.

Zhu, W. 2019. If you are physically fit, you will live a longer and healthier life: An interview with Dr. Steven N. Blair. J Sport Health Sci., 8, pp.524-6.

Zhu, W. 2020. Should, and how can, exercise be done during a coronavirus outbreak? An interview with Dr. Jeffrey A. Woods. J Sport Health Sci., 9, pp.105-7. 
110 | Yuliana 